\title{
Eschatological aspects of the Twelve Tribes' teachings: A theological perspective
}

\author{
Mgr. Anna Pokorná
}

https://doi.org/10.14712/25704893.2018.1

\begin{abstract}
In this text, I offer a basic description of the theology of the Twelve Tribes movement based both on a research study of relevant written sources and on participant observation and interviews with the members of the Twelve Tribes community of Mšecké Žehrovice. I focus especially on the eschatological expectations. The study explains the core motivations of the members' beliefs, such as the intent to return to the ideal of God's creation. In their endeavors, they use two portions of the biblical tradition - the first four generations of Abraham's family and, again, first four generations of the Early Church. According to the Twelve Tribes, both traditions represent historically successful intents to form God's true people. The article explains the evolution of the covenant between God and his people and the way the movement recognizes it in history. I concentrate both on the content the Twelve Tribes adopted from its sources in Old and New Testament and on its critical evaluation. Nevertheless, the core emphasis of the article is the movement's eschatology. It is precisely this dimension of their teachings that represents the main ambition of the Twelve Tribes: that is, to help with the transformation of the eras and earn the right to call themselves God's true people. The theological view of this New Religious Movement's belief and practice, which I present in this study, also covers the controversial topics of child training and closed community life.
\end{abstract}

Keywords: The Twelve Tribes community; millennialism; communal life; New Religious Movements; children in New Religious Movements

\begin{abstract}
Abstrakt: Na základě rozhovorů se členy společenství, zúčastněných pozorování v komunitě ve Mšeckých Žehrovicích a studia dostupné literatury předkládám $\mathrm{v}$ textu základní popis teologie a praxe společenství Dvanáct kmenů se zvláštním zřetelem na eschatologická očekávání komunity. Tato studie vysvětluje hlavní motiv víry členů společenství jako snahu o návrat $\mathrm{k}$ ideálu Božího stvoření. $\mathrm{V}$ tomto úsilí jsou jim vzory zejména dva úseky biblické tradice první čtyři generace Abrahamovy rodiny a stejný úsek první apoštolské církve. Obě tradice považuje Dvanáct kmenů za historicky částečně úspěšné pokusy o formaci pravého Božího lidu. Studie předkládá vývoj vztahu smlouvy Božího lidu s Bohem tak, jak jej společenství Dvanáct kmenů sleduje v dějinách. Pozornost je věnována jak prvkům, které od starozákonního i novozákonního pravzoru společenství Dvanáct kmenů převzalo, tak kritické zhodnocení obou duchovních předchůdců. Hlavní zřetel je ve studii brán na eschatologii společenství. V ní se soustředují ambice společenství napomoci transformaci věků a dosáhnout tak oprávněnosti titulu pravého Božího lidu. Teologický pohled na víru a praxi tohoto nového náboženského hnutí předložený v této studii se také dotýká kontroverzních témat výchovy dětí a uzavřeného komunitního života.
\end{abstract}

Klíčová slova: Dvanáct kmenů; milenialismus; komunitní život; nová náboženská hnutí; děti v nových náboženských hnutích

Received: 28 March 2017, Accepted: 17 October 2017

Published online: 28 May 2018

Mgr. Anna Pokorná, Evangelical Theological Faculty, Charles University, Prague

E-mail: pokorna.ann@gmail.com

(C) 2017 The Author. This is an open-access article distributed under the terms of the Creative

Commons Attribution License (http://creativecommons.org/licenses/by/4.0). 


\section{Introduction}

This text is a basic introduction to the theology of the Twelve Tribes movement seen through its eschatology. I believe that a general summary of the movement's faith may help all those interested in it to reach a better understanding of the movement's life and contribute to scholarly discussions ranging through different disciplines. The description of the movement's theology represents a specific view of how the group understands its own position, both in a historical context and in the context of contemporary society, and thus helps to explain the often incongruous types of the movement's spiritual practices.

It is precisely the spiritual practice of this closed community that may seem controversial to outside society - especially in cases when its description is not accompanied by theological explanation. In this context, the media often inform the larger public of specific types of the movement's parenting practices (spanking with a rod, ego repressing, adolescence spent in an isolated environment) and of raids during which the children of the movement's members were taken away by the authorities. Naturally, it is not a concern of theological studies to explain the possible controversies that arise from the Twelve Tribes' specific child-rearing or even to defend the movement against them. On the other hand, we should take in account the spiritual foundations of those parenting practices. Therefore, if we stick to the child-rearing example, theological understanding may contribute to a discussion with the Twelve Tribes by explaining to the public the logic of this strict parenting and understand why the movement sees the larger society's call for change in those practices as problematic. In much the same way, a general introduction to the movement's beliefs may be useful in explaining other aspects of the Twelve Tribes' life: it may help to clarify the theological motivation behind the movement's isolation or explain the importance of eschatological expectations of the movement as a whole.

\section{Methodology}

The following results of the Twelve Tribes' theology investigation are based both on a study of the movement's texts and on personal interviews with the Twelve Tribes members I accumulated during my fieldwork in the community of Mšecké Žehrovice. The written sources created by the movement may be divided into two subgroups first, texts intended for the public (missionary texts), and second, internal texts meant for the exclusive use of the movement's members. While the movement freely distributes the missionary texts during its public activities, the internal texts are only physically available in the communities (this applies to the four volumes of the socalled Books of Teachings). Due to actions of apostates, the texts are also available on the Internet (see Bibliography); however, I compared those materials during my fieldwork in the community with the official printed versions so that I could check the authenticity of the online version. During the participant observation in the move- 
ment I also underwent a series of discussions and talks with the community members, mostly of informal character; those helped to clarify unwritten and unofficial rules and customs of the movement.

In this paper, I chose to focus mainly on the eschatological dimension. The eschatological perspective represents the core of the movement's motivation and strongly appears in other loci theologici of this New Religious Movement. This also means that even if we focus solely on the eschatological theme, we still cover a wider scope of the movement's theology. Due to the character of the eschatological topics, the paper also needs to deal with the concept of the creation. I present the material through the methods of descriptive theology. In order to make the article's structure more transparent, I reserved the theological analysis for the conclusion.

\section{God's intention for mankind and human failure}

In the hermeneutics of history that form the nucleus of the Twelve Tribes' theology we can see a dualistic tension between the Good and the Evil, which acts as the origin of everything. ${ }^{1}$ The evil forces plunged the originally good world into chaos ${ }^{2}$ and in response to this situation, God created man to his image as an eternal spiritual being, ${ }^{3}$ whose role it is to defend the good in the world. This means that unlike the rest of the creation, Adam the Man was capable of living a deeper spiritual life. ${ }^{4}$ Adam's substance, due to which he was close to God, was supposed to ensure mankind's resistance against Evil. Also thanks to this substance, man was entrusted with the rule of the world and the whole of creation. ${ }^{5}$ According to the Twelve Tribes, man's fundamental task (that God assigned him with during the creation) is to become the representative of God's rule upon the world and to help eradicate the Evil.

In accordance to their original purpose, the first people lived in the Garden of Eden only for a limited period of time. The situation changed in the moment when God's forbade the first people to eat from the tree of knowledge of good and evil and they failed to obey. ${ }^{6}$ This insubordination, regarded in traditional theology as "the Fall of Man", meant that man diverged from his original purpose and became a sinner by nature. According to the Twelve Tribes, sin is the state of alienation from God. ${ }^{7}$

1 In the movement's theology, he appears personified as an antipode of the Good (that is, God), a fallen angel or Satan (also known as The Evil One or simply the Evil).

2 Which is an interpretation of Gn 1:2.

3 “Back to The Garden" (online), twelvetribes.org, 2014, accessed January 2016, available online at http://twelvetribes.org.

4 “The Majestic Ones" (online), twelvetribes.org, 2012, accessed October 2016, available online at http://twelvetribes.org.

5 “The Parable of Fascination" (online), twelvetribes.org, 2016, accessed November 2016, available online at http:/ / twelvetribes.org.

6 Genesis 3; "Adam and Eve - The Fall" (online), question12tribes.com, accessed November 2016, available online at http://question12tribes.com/tt-teachings/.

7 S. R. Lavin, God's People: In Search of a Destiny - A Look Into Life in the Twelve Tribes Community, Amazon Digital Services LLC, 2016, loc 2041. 
Under the yoke of sin, the character of human existence changed and Adam ceased to be an eternal spiritual being. At the same time, the origin of sin brought about the introduction of death into human life. Another attribute of the fallen creation is the innate conscience. The sinful mankind lost its original closeness to God and it gained an instinctive awareness of the Good and the Evil instead. ${ }^{8}$ While good deeds make people happy, evil deeds create a "bad conscience". ${ }^{9}$ At the same time, by the fall into sin, the human nature lost its ability to resist Evil and became quite prone to it. According to the Twelve Tribes, while conscience allows mankind to resist the forces of Evil, it does so only to some extent.

\section{Natural law}

According to the Twelve Tribes' teachings, in the world after the Fall of Man, the clear distinction between the Good and the Evil is called the natural law. This term refers to a series of laws that are natural for the world and therefore lead mankind to its nature; that is why the law is called natural. Alternately, the natural law is also called the eternal covenant; this covenant was established by God for the new (damaged) state of humanity. ${ }^{10}$ The content of the natural law can be recognized both in God's reaction to the Fall of $\mathrm{Man}^{11}$ and in the covenant God later established with Noah. ${ }^{12}$ Part of the natural law sentences the man to work hard do provide for his family, while the woman is supposed to bear children with painful effort. ${ }^{13}$ According to the Twelve Tribes, the covenant with Noah broadens the natural law with the instruction to have a plenty of children, to refrain from eating blood and to punish the shedding of human blood with death penalty. ${ }^{14}$

The natural law is valid for all the nations founded by Noah's descendants. ${ }^{15}$ As long as they keep fulfilling the covenant, their societies remain healthy and protected from the decadence that dates from the times immediately before the Flood. ${ }^{16}$ The Twelve

8 "Adam and Eve - The Fall", http://question12tribes.com/tt-teachings/. See also Genesis 3:22: "Then the LORD God said, Behold, the man has become like one of Us, knowing good and evil; and now, he might stretch out his hand, and take also from the tree of life, and eat, and live forever."

9 "Maladies" (online), twelvetribes.org, 2015, accessed October 2016, available online at http:// twelvetribes.org.

10 "Back to the Garden", http://twelvetribes.org.

${ }^{11}$ Genesis 3:16-19: To the woman he said, "I will make your pains in childbearing very severe; with painful labor you will give birth to children. Your desire will be for your husband, and he will rule over you." To Adam he said, "Because you listened to your wife and ate fruit from the tree about which I commanded you, 'You must not eat from it,' "Cursed is the ground because of you; through painful toil you will eat food from it all the days of your life. It will produce thorns and thistles for you, and you will eat the plants of the field. By the sweat of your brow you will eat your food until you return to the ground, since from it you were taken; for dust you are and to dust you will return."

${ }^{12}$ Genesis 9:1-7.

13 "Back to the Garden", http://twelvetribes.org, p. 10.

14 "Back to the Garden", http://twelvetribes.org, p. 18.

15 "Back to the Garden", http://twelvetribes.org, p. 11.

16 "Back to the Garden", http://twelvetribes.org, p. 18. 
Tribes illustrate this antediluvian disrespect of the natural law on the examples of the murder of $\mathrm{Abel}^{17}$ or the building of the Tower of Babel. ${ }^{18}$ At the same time, the movement insists the consequences of trespassing against the natural law have been apparent until now, in a global context. According to the movement's teachings, the first part of the natural law goes against states establishing unemployment benefits, since it is contrary to the principle of man's hard work, through which he maintains his family. ${ }^{19}$ The same applies to childbirth - it is unacceptable to bear a child in a hospital since it may result in accepting an epidural anesthesia. ${ }^{20}$ Consequences of Noah's covenant also lead the Twelve Tribes to conclude that those governments that shun the capital punishment of murder are acting against the natural law. ${ }^{21}$ Generally, the movement considers the state of the world to be unsatisfactory and interprets the situation as the result of general disrespect of the natural law and ignorance of the innate conscience. ${ }^{22}$ The opposite of life lead by the natural law is the life controlled by human righteousness. ${ }^{23}$ This type of life is always rooted in Evil.

\section{The first intent to re-create the ideal of the creation: Abraham's offspring and the decadence of Israel}

In the Twelve Tribes theology, the eternal covenant represents an obligation applicable to everyone (including the unbelievers). The members of the movement, on the other hand, relate more to a special covenant meant for God's people. This is due to the idea that while the natural law keeps the world more or less in balance between the Good and the Evil, it is not an adequate tool to eradicate the Evil completely. The teachings insist that even after the Fall of Man, God kept in mind his original closeness with humans. He thus called Abram (Abraham) and through him he begun a radical reinstating of the world and man's purpose. For this reason, the core binding "document" for the movement's members is God's covenant with Abraham. ${ }^{24}$ This agreement establishes a chosen people set apart for God's service. ${ }^{25}$ Biblically said, while the obligation to live according to the natural law binds the nations, the covenant with Abraham binds the Chosen People. ${ }^{26}$ On the other hand, this does not

\footnotetext{
${ }^{17}$ Genesis $4: 8$.

${ }^{18}$ Genesis 11:3-9.

19 "Instinctive Knowledge and Second Covenant" (online), question12tribes.com, 1995, accessed September 2016, available online at http://question12tribes.com/tt-teachings/.

20 "Instinctive Knowledge and Second Covenant", http://question12tribes.com/tt-teachings/.

21 "Instinctive Knowledge and Second Covenant", http://question12tribes.com/tt-teachings/.

22 "Earth: The Final Century" (online), twelvetribes.org, accessed May 2017, available online at http://twelvetribes.org.

${ }^{23}$ Based on this type of thinking, the Twelve Tribes criticize, among others, the idea of human rights.

${ }^{24}$ Genesis 15.

25 "Israel: The Seed of Abraham" (online), twelvetribes.org, 2015, accessed November 2016, available online at http://twelvetribes.org.

26 "Instinctive Knowledge and Second Covenant", http://question12tribes.com/tt-teachings/.
} 
mean Abraham's covenant is in any conflict with the eternal covenant. For God's people, acting in accordance with the natural law should be a matter of course. At the same time, the special covenant creates special obligations for the Chosen People, since it requires a return to the original purpose of man and reinstates a personal relationship with God.

In the Twelve Tribes movement, Abraham enjoys special respect and popularity. The teachings emphasize the care with which Abraham provided for his family as a father ${ }^{27}$ and appreciate the stress the first generations of his offspring put on spreading the gospel of God's righteousness and justice in raising their children. ${ }^{28}$ For the Twelve tribes, this interest in children is extremely typical. Even though the core motivation for child training can be found in the eschatological perspective, the movement finds its original inspiration in the Abrahamic cycle. All the context of Abraham's life as well as the meaning of the name Abraham ("the father of many") suggests the supreme importance of plentiful offspring. ${ }^{29}$

According to the Twelve Tribes, the people that follow Abraham's special covenant (e.g. the Chosen People) are supposed to be a living proof of God's righteousness in the world. ${ }^{30}$ Abraham's offspring declared this specific calling of God's people by means of circumcision and through different annual feasts in God's honor. ${ }^{31}$ According to the movement, the success of God's people manifests in the ability to keep the seventh day holy; that is, to celebrate the Sabbath. ${ }^{32}$ The movement insists that the duty to observe the Sabbath is the most important of the Ten Commandments. ${ }^{33}$ Nevertheless according to the Twelve Tribes, only four generations were actually able to fulfill the terms of Abraham's covenant. In all of the Hebrew Bible, only Abraham, Isaac, Jacob and Jacob's sons, who created the twelve tribes of Israel, are supposed to be the true representatives of God's Chosen People.

Based on the rest of the Old Testament's texts, the Twelve Tribes insist that the later people of Israel have forsaken the ideal and ceased to be a nation set apart for God. According to the movement, the decadence of the Chosen People is caused by the process in which Israel started to adopt other nations' moral values ${ }^{34}$ and failed to perform its role of people set apart for God's service. ${ }^{35}$ The Twelve Tribes interpret the corruption of the Chosen People as an inability to resist external pressures of the nations, practical examples of this process being idolatry or increasing social injus-

27 "Suspended Animation" (online), twelvetribes.org, 2016, accessed November 2016, available online at http://twelvetribes.org.

28 "Restoring the Ancient Way of Genesis 18:19" (online), twelvetribes.org, 2016, accessed November 2016, available online at http://twelvetribes.org.

29 "Faith of Abraham" (online), twelvetribes.org, 2015, accessed October 2016, available online at http://twelvetribes.org.

30 "Israel: The Seed of Abraham", http://twelvetribes.org.

31 "Israel: The Seed of Abraham", http://twelvetribes.org.

32 "Sabbath - the Signifier" (online), question12tribes.com, 1995, accessed October 2016, available online at http://question12tribes.com/tt-teachings/.

33 "Sabbath - the Signifier", http://question12tribes.com/tt-teachings/.

34 "Israel: The Seed of Abraham", http://twelvetribes.org.

35 "Suspended Animation", http://twelvetribes.org. 
tice. ${ }^{36}$ The journey of Israel from Egypt to the Promised Land is filled with cases of the loss of identity of God's people. And finally, a marked symbolic proof of a failure to uphold the ideal of God's people is the Law that Moses brought to Israel. ${ }^{37}$ According to the teachings, the stone slabs inscribed with the Law are a concrete proof of the fact that Abraham's offspring abandoned its original good deeds. While Abraham's children still had the Law in their hearts (and therefore automatically acted according to God's righteousness), in case of the obstinate Israel it had to be inscribed in stone and brought by Moses. ${ }^{38}$ According to the Twelve Tribes, the Law generally corresponds to the actual life of Abraham's children; nevertheless, Abraham himself already followed the Law four hundred years before it was established on Sinai. ${ }^{39}$ That means that for the members of the movement, not only the content of the covenant is important, but also the inner motivation with which it is kept. This is also the reason why the Twelve Tribes put so much stress on Abraham's acts, despite of the superficial similarities in the behavior of Israel. At the same time, the movement maintains a spiritual distance from Jewish religion, which was created from the original faith of Abraham. ${ }^{40}$ The community of the Synagogue ceased to fulfill the function of the Chosen People - they started to focus on ritual practice and Scripture reading instead of life of faith. And ultimately, Israel's status as God's people finally ended when, during the Exile, the unified twelve tribes finally dissolved..$^{41}$ In the movement's theology, the tribes represent the true nature of Israel: therefore, God's Chosen People cannot abide without them. ${ }^{42}$ Another visible sign of corruption is the inability of later generations of the Israeli to celebrate Shabbat properly. ${ }^{43}$

\section{Yahshua, the New Adam - new conditions of restoration}

According to the Twelve Tribes, the New Testament confirms there was another attempt to restore the original creation - in this case, the God's people were represented by the Early Church. Nevertheless, due to the failure of Israel, the "process of restoration" was changed and in the New Testament, the core protagonist of the restoration was Jesus the Son of God. Only instead of "Jesus", the Twelve Tribes call him "Yahshua", an allegedly original Hebrew form of the Greek name Iésus. ${ }^{44}$ This is

\footnotetext{
36 “Suspended Animation”, http://twelvetribes.org.

37 "Chosen to Walk Like Abraham" (online), question12tribes.com, 1992, accessed October 2016, available online at http://question12tribes.com/tt-teachings/.

38 "Chosen to Walk Like Abraham”, http://question12tribes.com/tt-teachings/.

39 "Chosen to Walk Like Abraham", http://question12tribes.com/tt-teachings/.

${ }^{40}$ This information is based on the Author's interview with a Twelve Tribes male community elder. Anonym C, Mšecké Žehrovice, 18. 12. 2015.

${ }_{41}$ "Natural Israel" (online), question12tribes.com, 1992, accessed October 2016, available online at http://question12tribes.com/tt-teachings/.

42 "Natural Israel", http://question12tribes.com/tt-teachings/.

43 "Sabbath - the Signifier", http://question12tribes.com/tt-teachings/.

44 "The Name Above All Names" (online), twelvetribes.org, 2016, accessed November 2016, available online at http://twelvetribes.org.
} 
based on the idea that since Jesus was a Jew and since the Jews spoke Hebrew, it was the name "Yahshua" that Archangel Gabriel brought to Mary. ${ }^{45}$ The Twelve Tribes attach great importance to the Hebrew name's significance - as the movement often insists, Yah-shua means "the God's Salvation". ${ }^{46}$

For the community, Yahshua represents the perfect man, who matches God's original concept of creation. ${ }^{47}$ Moreover, he has the privilege to bring his followers to this original perfection. According to the movement, Yahshua was born as a human child that was devoid of the fallen creation's sins.$^{48}$ In the same sense, the Twelve Tribes explore St. Paul's thought from The First Epistle to the Corinthians. ${ }^{49}$ Here the Apostle calls Yahshua "the second Adam" or "the last Adam"..$^{50}$ Both the first Adam and Yahshua (the second Adam) had a common state of origin - neither was burdened by sin. Nevertheless, in the Twelve Tribes' interpretation, Yahshua surpassed Adam because he never left God's presence and never disobeyed him. ${ }^{51}$ By calling him "the last Adam", the movement expresses its belief that after Yahshua, no similar man will ever be born..$^{52}$

The Twelve Tribes consider Yahshua's death on the cross and his resurrection to be the core moment of his life..$^{53}$ The movement understands Yahshua's death as the supreme sacrifice, ${ }^{54}$ which has power to bring mankind closer to God. ${ }^{55}$ In order to reach a better understanding of the place that Yahshua's death holds in the movement's theology, we need to recall that human death is considered to be a negative attribute of the Fall of Man; death itself is understood as a kind of payment for the corrupted state of mankind. Every person must pay for the original sin by his or her death; in the eternity, it is the only way we can become spiritual beings again. In the

45 “The Name Above All Names", http://twelvetribes.org.

46 "The Name Above All Names", http://twelvetribes.org.

${ }^{47}$ The stress on Yahshua's true humanity leads to the question to which extent (or if at all) the Twelve Tribes consider Yahshua to be God. It seems that in the movement's theology, no emphasis is put on Jesus' divinity and if we consider the exceptional and central status of God the Creator, it may not even be compatible with the movement's teachings. This is further confirmed by the words of one of the community members spoken during the meeting of the Twelve Tribes with the public in 2004 in Nelson, Canada. The person said in front of witnesses he does not consider Yahshua to be God. For a report of the meeting see "The Twelve Tribes: Who are They?" (online), $M M$ outreach, 2004, accessed November 2016, available online at http://mmoutreachinc.com/cult groups/12tribes.html.

48 “The Unshakable Certainty" (online), twelvetribes.org, 2012, accessed November 2016, available online at http://twelvetribes.org.

491 Corinthians 15:45.

50 “A Suitable Helper" (online), twelvetribes.org, 2015, accessed November 2016, available online at http://twelvetribes.org.

51 “The Three Eternal Destinies: Adam and Messiah" (online), question12tribes.com, 1998, accessed October 2016, available online at http://question12tribes.com/tt-teachings/.

52 “The Purpose of Creation \& Redemption", (online), twelvetribes.org, 2016, accessed September 2016, available online at http://twelvetribes.org, p. 22.

53 “The Purpose of Creation \& Redemption", http://twelvetribes.org, p. 4.

${ }^{54}$ In the movement's theology, Abraham's sacrifice of Isaac is understood as an analogy to the sacrifice of the Son of God.

55 “The Gospel of the Cross" (online), twelvetribes.org, 2016, accessed May 2017, available online at http://twelvetribes.org. 
perspective of these beliefs, the movement understands Yahshua's death as God's substitute payment for the human nature corrupted by sin. ${ }^{56}$ By Yahshua's death, which paid a price for the whole of mankind, God actually gave human beings a gift. Yahshua's death represents God's will for reconciliation that leads to the successful restoration of mankind. The death of the Son of God is literally understood as a "ransom"..$^{57}$ All those who claim Yahshua's sacrifice and imitate him by living a life of servanthood to God will be redeemed; by following Yahshua's example, his disciples can break free from sin and return to God's proximity, which was enjoyed by Adam before the fall. ${ }^{58}$ The ability to abandon the corrupted state of mankind is brought about by offering of one's life to God every day. ${ }^{59}$

In the context of the coming of Yahshua, the movement operates with the idea of the return of the covenant "into the heart", connecting it symbolically to its opposite, the covenant (the Law) inscribed on the stone slabs. ${ }^{60}$ Those that follow the God's covenant (in his Spirit) by accepting Yahshua as the Messiah fulfill the requirements of the covenant: in the perspective of the Old Testament, these consist of service to God. By its service, God's people reflect God's righteousness. In the terms of the New Testament, this is parallel to a life lived according to God's righteousness, following the principles of the Kingdom of God. According to the Twelve Tribes, this type of life is the program of Yahshua's teachings ${ }^{61}$ that coincides with the application of God's righteousness in the world. Yahshua was constantly explaining the principles of the Kingdom of God to his followers, both by his sermons and his own example. Moreover, after the Ascension he instructed them to proclaim that the Kingdom of God will arrive within this age. ${ }^{62}$ Nevertheless, the Kingdom will have its major say in the following era. The Kingdom of God on Earth as represented by God's people today only heralds or reveals the upcoming state of the world that will take place in the following age.

\section{Second intent to restore the original state - the Early Church and its corruption}

For the Twelve Tribes, the second example of God's faithful people is the Early Church as described by the Acts of the Apostles. The members of the Early Church

\footnotetext{
56 “The Purpose of Creation \& Redemption”, http://twelvetribes.org, p. 7.

57 "Redemption" (online), question12tribes.com, 1995, accessed October 2016, available online at http://question12tribes.com/tt-teachings/.

58 "The Gospel of the Cross", http://twelvetribes.org.

59 "The Gospel of the Cross", http://twelvetribes.org.

60 "Re-establishment the Covenant" (online), question12tribes.com, 1992, accessed October 2016, available online at http://question12tribes.com/tt-teachings/. See also the analogical comparison of Abraham's and Moises' covenants.

${ }_{61}$ “Where Did the Gospel Come From?” (online), twelvetribes.org, 2016, accessed August 2016, available online at http://twelvetribes.org.

62 “The Black Box" (online), twelvetribes.org, 2016, accessed March 2017, available online at http:// twelvetribes.org.
} 
accepted Yahshua as the Lord, renewed the covenant in their hearts and became the witnesses of the Kingdom of God on Earth - in other words, they became the new bearers of the title of God's people (thus turning into a spiritual Israel). Due to the fact that the Church emerged immediately after Yahshua's Ascension and thanks to the Book of Acts, which captured the way the Holy Spirit affected the Early Church, the Twelve Tribes consider Luke's image of the Early Church to be the only model of God's people that it is at the moment possible to imitate. ${ }^{63}$ The movement insists that the core feature of the Early Church, inspired by the respect to Abraham's offspring, was the renewal of the tribal organization. This fact affirmed by the Old Testament is further confirmed by Acts 26:7 - therefore, the new formation of the tribes is a necessary part of restoration of God's people. ${ }^{64}$

According to the Twelve Tribes, the triumph of this first community was only possible through the influence of the Holy Spirit, which acted as an intermediary between the people and God's will and continued Yahshua's work on Earth. Another important reason why the community was so successful is the direct personal instruction Yahshua gave to its founders, his disciples. ${ }^{65}$ People, changed by the power of the Holy Spirit, ${ }^{66}$ followed the Apostles, who in turn were authorized by Yahshua to "teach them to obey everything I have commanded you" ${ }^{67}$ To the Twelve Tribes, the apostolic teaching based on the second chapter of the Acts of the Apostles became one of the four pillars of the Church. ${ }^{68}$ The other pillars are communal life (koinónia in Greek), the breaking of bread, and prayers. ${ }^{69}$ According to the movement, a koinónia takes place if the believers partake in three following things - participation, contribution and distribution. ${ }^{70}$ Participation means an active presence in communal life upon every occasion. According to the Twelve Tribes, a member of the community is supposed to contribute to the success of these events both by personal endeavor and by sharing material means and personal efforts. ${ }^{71}$ These three requirements are the core conditions that need to be met to produce the "fruit" of Yahshua's following. ${ }^{72}$ According to the Twelve Tribes, Yahshua's call for unity is fulfilled by communal devotion. ${ }^{73}$ The third pillar, the breaking of bread, is not understood as syn-

63 "The Gospel of the Cross", http://twelvetribes.org. "Why We Live in Communities", (online), question12tribes.com, 1995, accessed October 2016, available online at http://question12tribes .com/tt-teachings/.

64 "Why Twelve Tribes" (online), twelvetribes.org, 2015, accessed November 2016, available online at http://twelvetribes.org.

65 "Abraham's descendants" (online), question12tribes.com, 1992, accessed October 2016, available online at http://question12tribes.com/tt-teachings/.

66 "Abraham's descendants", http://question12tribes.com/tt-teachings/.

${ }^{67}$ This is an interpretation of Matthew 28:20 according to "Apostle's Teachings Acts 2:42" (online), question12tribes.com, 1995, accessed October 2016, available online at http://question12tribes. com/tt-teachings/.

${ }^{68}$ Acts 2:42.

69 “The Purpose of Creation \& Redemption", http://twelvetribes.org, p. 10.

70 "Apostle's Teaching Acts 2:42", http://question12tribes.com/tt-teachings/.

71 "Apostle's Teaching Acts 2:42", http://question12tribes.com/tt-teachings/.

72 "Apostle's Teaching Acts 2:42", http://question12tribes.com/tt-teachings/.

${ }^{73}$ John 17:20-23. 
onymous with the Eucharist - instead, it denotes a wider concept that incorporates the Eucharist as well as the week-long preparation that precedes the ceremony. This preparation also includes confession of sins and thanksgiving. ${ }^{74}$ Prayers, the last of the four pillars, applies both to individual prayers and communal prayers that take place during gatherings. ${ }^{75}$

Other frequently quoted verses of the Acts are those that mention communal property. ${ }^{76}$ For the Twelve Tribes, the second and third chapter of the Acts that deal with sharing communal life and collective property express a necessary aspect of the God's people's life. Luke's description of the communal life of the first followers of Christ is understood as an imperative. According to the Twelve Tribes, joint property and communal life are necessary conditions for the fulfillment of Yahshua's will. The Kingdom of God exists only in those communities that share material goods so that nobody lacks anything. Holy Spirit provides the strength that the newly christened need to leave their former lives (including leaving their property) and embrace a communal life. ${ }^{77}$

Nevertheless, the Twelve Tribes insist that, just as with Abraham's offspring, the Early Church's active efforts to fulfill the conditions of God's Kingdom lasted only four generations. According to the movement, the cause of the corruption was the change of the Early Church into a synagogue. ${ }^{78}$ By changing its liturgical life, the Early Church abandoned its communal character and its connection to the Holy Spirit vanished. ${ }^{79}$ Consequently, they lost the ability to resist Evil. According to the Twelve Tribes' teachings, if a man tries to fight the forces of Evil without the necessary help of the Holy Spirit, he is in grave danger: the evil forces disappear, leaving an empty space behind, and if the Holy Spirit does not fill it, new and more powerful evil forces come to reside there. ${ }^{80}$ Thus when the Early Church lost its connection to the Holy Spirit, it was populated with forces of Evil; according to the Twelve Tribes, this became one of the most important reasons for its fall. ${ }^{81}$ An alternative explanation of its corruption is also the emergence of Christianity: ${ }^{82}$ just as in Israel's case, it was the abandoning of Sabbath celebration that became the most tangible manifestation of the Church's corruption. ${ }^{83}$

74 “The Purpose of Creation \& Redemption”, http://twelvetribes.org, p. 10.

75 "The Purpose of Creation \& Redemption", http://twelvetribes.org, p. 10.

${ }^{76}$ Acts 2:44; 4:32. Since these two verses are considered to be the core pillars of the Twelve Tribes community life, they are included in the short description of the communities in the movement's printed materials.

77 "Community at the Crossroads" (online), twelvetribes.org, 2015, accessed in April 2017, available online at http://twelvetribes.org.

78 "The Anatomy of the Fall of the First Church" (online), question12tribes.com, 1995, accessed October 2016, available online at http://question12tribes.com/tt-teachings/.

79 “The Anatomy of the Fall of the First Church", http:/ question12tribes.com/tt-teachings/.

80 "The Anatomy of the Fall of the First Church", http://question12tribes.com/tt-teachings/.

81 "The Anatomy of the Fall of the First Church", http://question12tribes.com/tt-teachings/.

82 "The Fall of The First Church" (online), question12tribes.com, accessed November 2016, available online at http://question12tribes.com/tt-teachings/.

83 "Restoration of the Sabbath" (online), question12tribes.com, 1995, accessed November 2016, available online at http://question12tribes.com/tt-teachings/. 


\section{Third intent to restore the original state - the Twelve Tribes movement}

In their religious practice, the Twelve Tribes are inspired both by the life of Abraham's offspring and by the Early Church as described in the Acts of the Apostles. Both these models represent the model life of God's people established by God. At the same time, the movement also insists that unlike Abraham's offspring and the Early Church, the Twelve Tribes will be successful in fulfilling God's intent to restore the original state of the creation. ${ }^{84}$ In the effort to avoid its predecessor's mistakes, the movement puts great stress on isolated community life and rigorous child training.

The Twelve Tribes movement uses two titles for itself - the first is the Hebrew term Edah, the second is the Body (that is, the body of the Savior or of Yahshua). The latter has its origins in the New Testament's image of the Church as a body, while the former, inspired by the Book of Jeremiah, expresses the Hebrew background of the movement. ${ }^{85}$ While the Old Testament Hebrew Lexicon translates edah as "congregation" or "gathering", the Twelve Tribes base their interpretation on the root ed, which means "witness" ${ }^{86}$ For the movement, the term Edah thus represents a reminder that they are the witnesses of the Kingdom of God. Another less frequent meaning of the word edah is "beehive"; the Twelve Tribes use it as a metaphor for their communal life, in which, just as in the beehive, all the members unselfishly serve a common goal. ${ }^{87}$ The concept of the "Body" (of the Savior) reminds the movement of the Early Church's heritage. Thanks to following Yahshua's example and to the power of the Holy Spirit, members of the Twelve Tribes are spiritually incorporated in the Messiah. ${ }^{88}$ And according to the movement, after Yahshua's Ascension his followers in the Early Church became his real resurrected body on Earth. ${ }^{89}$ The term also expresses the exclusive gifts of the Holy Spirit that the movement believes to receive. The Holy Spirit, which formerly dwelled in Yahshua's mortal form, resides today only in his Body. ${ }^{90}$

We should therefore understand the isolated community life of the Edah/Body specifically as a life that is exclusively reserved for God and, as such, it fulfills the duty of the Chosen People. Yes, the recommended limited contact with the surrounding world is also motivated by the desire to live outside of the realm where the powers of Evil reign. But at the same time, the movement insists that striving for a greater

84 "The Voice From Outside the Camp of Organized Religion: Last Day" (online), twelvetribes.org, 2007, accessed November 2016, available online at http://twelvetribes.org.

${ }^{85}$ Jeremiah 30:20. "Their children also shall be as aforetime, and their congregation shall be established before me, and I will punish all that oppress them."

86 "Ed Meets Edah" (online), twelvetribes.org, 2012, accessed January 2017, available online at http:// twelvetribes.org.

87 "The Purpose of Creation \& Redemption", http://twelvetribes.org, p. 44.

88 "Incorporated in Messiah" (online), question12tribes.com, 1995, accessed November 2016, available online at http://question12tribes.com/tt-teachings/.

89 "Nightfall" (online), twelvetribes.org, 2016, accessed February 2017, available online at http:// twelvetribes.org.

90 "Nightfall", http://twelvetribes.org. 
closeness to God and proper service to Him greatly surpasses the importance to keep a distance from Satan. An important similarity with Abraham's offspring is also the stress on family and children. The Twelve Tribes understand the traditional model of family as fulfillment of a command that God issued after the creation of man and woman. ${ }^{91}$ Consequently, the communities comprise mostly of families living together. At the same time, the communities are geographically divided into tribes. ${ }^{92}$ Since the interpretation both of Abraham's era and the Early Church period stresses the importance of tribal organization, it is hardly surprising that tribal structure has become the key element both for the theology and the practice of the Twelve Tribes (even the name of the movement itself recalls the twelve tribes of Israel). In the Bible, tribal organization is emphasized in Isaiah's prophecy of restoration of the tribes of Jacob ${ }^{93}$, as well as in Paul's testimony to Agrippa in the Acts of the Apostles. ${ }^{94}$

For the Twelve Tribes, communitarian life (or participation on the Messiah's Body) is a challenge to transform their life into everyday sacrifice..$^{95}$ The demand to follow Yahshua unconditionally is called the "Gospel of the Cross": ${ }^{66}$ in practice, this means that Yahshua's followers should repeat his sacrifice by means of surrendering everything that makes them distant from God. The followers are supposed to give up all earthly possessions and aspirations and fully embrace a life dedicated to God's Kingdom. ${ }^{97}$ Following the Early Church's example, the movement especially emphasizes communal property: its members have no personal finances. The image of Yahshua's Body and Edah fits well the collective spirit of the community, in which every member serves the needs of the whole organism, most notably its head (that is, Yahshua himself ). ${ }^{98} \mathrm{An}$ individual's sacrifice must also contain the spiritual sacrifice of his or her ego (which is the substance of the fallen creation) - this enables the person to return to God's proximity and leave his or her sins behind..$^{99}$ The Twelve Tribes view the human ego both as a bearer of false motivations and a fertile ground for the forces of Evil; it gathers imperfections from the spiritual struggle, as well as the imperfections we were born with or which we received from our education. The sum of all human imperfections (not only sin as such, but also each and every grievance

${ }^{91}$ Genesis 1:28a. "And God blessed them, and God said unto them, Be fruitful, and multiply, and replenish the earth, and subdue it."

${ }_{92}$ There are four tribes in the U.S. (Manasseh, Judah, Joseph and Benjamin) and four in Europe: France (Reuben), Spain (Simeon), Great Britain (Zebulon), and a former German community that now resides in the Czech Republic (Levi). Two are in the Latin America in Brazil (Naphtali) and Argentina (Issachar), one is in Australia (Asher) and one in Canada (Gad). Susan J. PALmer, “The Twelve Tribes: Preparing the Bride for Yahshua's Return", Nova Religio 13 (3/2010), p. 75.

${ }^{93}$ Isaiah 49:6.

${ }^{94}$ Acts 26:7. "And now I stand on trial because of my hope in the promise that God made to our fathers, the promise our twelve tribes are hoping to realize as they earnestly serve God day and night. It is because of this hope, $\mathrm{O}$ king, that I am accused by the Jews."

95 “The Gospel of the Cross", http://twelvetribes.org.

96 "The Gospel of the Cross", http://twelvetribes.org.

${ }_{97}$ "The Gospel of the Cross", http://twelvetribes.org.

${ }^{98}$ Ephesians 5:23: "For the husband is the head of the wife, even as Christ is the head of the church: and he is the saviour of the body."

${ }_{99}$ An interview by the Author with a married couple, Mšecké Žehrovice 8. 5. 2016. 
or act of selfishness) is called iniquities ${ }^{100}$ - and breaking out of this burden, whether inherited or caused by one's own mistakes, is only possible through the community and by means of Yahshua's redemption. ${ }^{101}$ An individual's spiritual path consists of prayers, an effort to act righteously and, most notably, active participation in communal life. ${ }^{102}$ Members of the Twelve Tribes believe that thanks to the exclusive influence of the Holy Spirit, their movement is the sole way to suppress the destructive human ego. In the community, the individual reaches his or her spiritual perfection through public confession of sins (that takes place during gatherings) or through a correction administered by one of the community elders. ${ }^{103}$

Naturally, celebration of the Sabbath occupies an important place in the community life of the Twelve Tribes. For the movement, the ability to keep this feast is a confirmation of their status as God's people. During the seventh day, the community members quit working and rest, having prepared their meals beforehand. At the same time they insist that unlike the Jews, they have no specific list of allowed or forbidden activities. ${ }^{104}$ Since appropriate celebration is rooted in spiritual readiness, the seventh day begins by a correct understanding of the rest day "in the believer's heart". On the Sabbath evening, the community serves a special meal that is considered to be the apex of the week..$^{105}$ The Twelve Tribes combine the celebration of the Sabbath with a Eucharistic dinner that expresses their unity with the Early Church. ${ }^{106}$ This dinner is celebrated after Sabbath, that is, on Saturday evening (which is considered to be the beginning of the new week), and acts as a reminder of Lord Yahshua's Resurrection..$^{107}$ Before the breaking of the bread (as the Twelve Tribes call the Eucharist), all the community members confess their sins committed during their spiritual battles of the last week. ${ }^{108}$ The confession is also the first part of the celebration, the so-called Victory Cup. Here, the Gospel of Luke serves as the biblical basis for this practice. ${ }^{109}$ Only those that successfully resisted sin during the previous week are allowed to drink from the Victory Cup ${ }^{110}$ - both baptized community members and unbaptized children can participate, the only requirement being success in the spiritual struggle. ${ }^{111}$ If a person's spiritual fight is considered to be unsuccessful, he or she cannot drink from the Cup. After the drinking, the breaking of the bread takes place. During it, a second Cup is shared by the community members and this time all the baptized members can drink from it, including those who were not allowed to taste the first one. The

\footnotetext{
${ }^{100}$ An interview by the Author with a married couple, Mšecké Žehrovice 8. 5. 2016.

${ }^{101}$ The application of Yahshua's sacrifice as a redemption from the sinful substance as such is, in this case, virtually limited on partial manifestations of sin.

${ }^{102}$ This applies to all three aspects of koinónia - participation, contribution, and distribution.

${ }^{103}$ An interview by the Author with a young woman, Mšecké Žehrovice 8. 5. 2016.

${ }^{104} \mathrm{An}$ interview by the Author with a male community elder, Mšecké Žehrovice, 18. 12. 2015.

${ }^{105}$ An interview by the Author with a male community elder, Mšecké Žehrovice, 18. 12. 2015.

${ }^{106}$ An interview by the Author with a married couple, Mšecké Žehrovice 8. 5. 2016.

${ }^{107}$ Palmer, "The Twelve Tribes", p. 71.

${ }^{108} \mathrm{An}$ interview by the Author with a married couple, Anonym A, Mšecké Žehrovice 8. 5. 2016.

${ }^{109}$ Luke 22:17-20.

${ }^{110}$ An interview by the Author with a young woman, Mšecké Žehrovice 8. 5. 2016

${ }^{111}$ An interview by the Author with a young woman, Mšecké Žehrovice 8. 5. 2016.
} 
breaking of bread ceremony has the format of a dinner and only permanent members of the community can participate. The combination of the Sabbath celebration and a variation of the Eucharist is one of the examples of how the movement's practices are connected to its beliefs that reflect the Twelve Tribes' self-understanding as the rightful heirs of the Chosen People.

\section{The Twelve Tribes' eschatology}

The most concentrated expression of Twelve Tribes' conviction that they represent God's true people (the spiritual Israel) can be found in their eschatological expectations. The strong eschatological orientation arises from the movement's self-interpretation as the basic condition of the transformation of the times. ${ }^{112}$ During this transformation, the age corrupted by Evil would change and revert back to God's original intention for the creation. The Twelve Tribes' core eschatological concept is the abovementioned world of the fallen creation that has been ruled by the forces of Evil ever since the Fall of Man. In this world, God's people live in isolation, resisting the Evil through its participation on the restored creation of the Kingdom of God. The movement's eschatology is steeped with criticism towards the acts of the offspring of Israel (or the "natural Israel"), as opposed to the true, spiritual Israel, which is represented by the movement itself. The movement understands itself as a new God's people, which has to take the role of the original (natural) Israel by producing the fruit of the Kingdom of God in its stead. ${ }^{113}$

The Twelve Tribes understand the present times as the last segment of this era's history. ${ }^{114}$ This idea is based on the biblical prophecies about the End Time, which, according to the Twelve Tribes, are being slowly fulfilled. ${ }^{115}$ One of the main arguments the Twelve Tribes use to support their idea of the approaching end of the contemporary era is an interpretation of the Book of Isaiah. The movement sees the current state of society as the fulfillment of the prophet's words about a confusion of the Good and the Evil, ${ }^{116}$ which is a sign of the End Time. ${ }^{117}$ The reason for the reversal of traditional values is the fact that society has broken away from the natural law. ${ }^{118}$ Although in the history of the fallen creation the law has never been followed fully, at least its main features were considered essential. Man was supposed to bring food to

\footnotetext{
${ }^{112}$ An interview by the Author with a married couple, Mšecké Žehrovice 8. 5. 2016.

113 “The Three Eternal Destinies \#105 My People Israel, the Holy” (online), question12tribes.com, 1997, accessed November 2016, available online at http://question12tribes.com/tt-teachings/.

114 "Earth: Final Century", http://twelvetribes.org.

${ }^{115}$ For the entire list of the prophecies see "The Voice From Outside the Camp of Organized Religion: Last Day" (online), twelvetribes.org, accessed November 2016, available online at http:// twelvetribes.org.

${ }^{116}$ Isaiah 5:20: "Woe unto them that call evil good, and good evil; that put darkness for light, and light for darkness; that put bitter for sweet, and sweet for bitter!"

117 "The Voice From Outside the Camp of Organized Religion: Last Day", http://twelvetribes.org, p. 13.

118 "Earth: Final Century", http://twelvetribes.org.
} 
his family, holding the position of an unquestionable authority; woman was supposed to respect her husband and bear him children with painful effort. Even though people occasionally resisted this natural law, social pressure helped to maintain it. However, contemporary phenomena such as changes in the male and female social role, liberal upbringing of children, the welfare system, and progress in modern medicine led to the values which the contemporary society praises being in direct contrast with the natural law. ${ }^{119}$ The Twelve Tribes specifically speak about secular humanism they considered it to be the enemy of the natural law ${ }^{120}$ and see it as the reason why the Good is not respected as the Good but shunned as the Evil. ${ }^{121}$ Another sign of the coming End Time is the state of the Earth's nature. An interesting moment in the apocalyptic interpretation of the contemporary world is the interpretation of the Book of Revelation, specifically of those verses that mention the Sun scorching men with fire. ${ }^{122}$ The Twelve Tribes see this as a warning against global warming. ${ }^{123}$

In an eschatological context, while the movement identifies with Isaiah's twelve tribes of Jacob's offspring, ${ }^{124}$ it also sees itself as the kingdom of stone mentioned in the Book of Daniel..$^{125}$ At the same time, it speaks about itself as the witness of the Kingdom of God mentioned by Jesus in the Gospel of Matthew. ${ }^{126}$ All these biblical terms express the eschatological context of the movement's identity and the Twelve Tribes use them interchangeably. The most frequently used biblical motif is the identification of the movement with the Bride meant for the Groom, which must undergo a purification process in order to call Yahshua back to earth and start the End Time events. $^{127}$

\section{The restoration of all things and the eschatological dimension of parenting}

The sings of the End Time are both a warning for mankind to return to the natural law and (most importantly) a sign for the God's people to fulfill its role in the apocalyptic events. The goal of the God's people is to take steps to ensure the triumph of

119 “The Voice From Outside the Camp of Organized Religion: Last Day”, http://twelvetribes.org, p. 13.

120 "What Was Normal Has Become Perverted" (online), question12tribes.com, accessed November 2016, available online at http://question12tribes.com/tt-teachings/.

121 "What Was Normal Has Become Perverted", http://question12tribes.com/tt-teachings/.

${ }^{122}$ Revelation 16:8ff.

${ }_{123}$ “The Voice From Outside the Camp of Organized Religion: Last Day", http://twelvetribes.org, p. 13.

${ }^{124}$ Isaiah 49:6: "It is too small a thing for you to be my servant to restore the tribes of Jacob and bring back those of Israel I have kept. I will also make you a light for the Gentiles, that my salvation may reach to the ends of the earth."

${ }^{125}$ Daniel 2:35, 44 and 45. See also the interpretation of Daniel's prophecy in the rest of the chapter.

${ }^{126}$ Matthew 24:14: "And this gospel of the kingdom will be preached in the whole world as a testimony to all nations, and then the end will come." "The Voice From Outside the Camp of Organized Religion: Last Day", http://twelvetribes.org, p. 27.

${ }^{127}$ According to the Gospel of John. See also PALmER, "The Twelve Tribes", p. 75; "The Voice From Outside the Camp of Organized Religion: Last Day”, http://twelvetribes.org, p. 27. 
the Kingdom of God on earth. ${ }^{128}$ From the eschatological point of view, this goal is termed "restoration of all things". The basis for this is the third chapter of the Acts of the Apostles ${ }^{129}$ - the Twelve Tribes insist that according to this text, the Second Coming (and therefore also the definitive end of our times) will only take place after the restoration of all things. ${ }^{130}$ For the movement, this means that the main condition under which the End Time can come is its own activity; this idea is also based on the Gospel of Matthew. ${ }^{131}$ Before the Apocalypse comes, people from outside of the community will receive God's will through the God's people. ${ }^{132}$ In other words: even now, long before the full restoration of the creation, God's people must put restoration at work in their community.

In the eschatological context, a symbolical expression of God's people's restoration is the image of God's people as a Woman or Bride, who expects the coming of the Groom (Yahshua) and prepares herself for him. ${ }^{133}$ The Twelve Tribes find support for this interpretation in the twelfth chapter of the Book of Revelation, which tells of "a woman clothed with the sun, with the moon under her feet and a crown of twelve stars on her head". ${ }^{134}$ The movement insists the twelve stars symbolize the Twelve Tribes. ${ }^{135}$ Yahshua the Messiah will not return until an "spotless Bride" is prepared for him. ${ }^{136}$ The reason for Yahshua's waiting is a logical consequence of the idea that God's people must be cleansed from their sins lest Yahshua should destroy them: according to the Twelve Tribes, during his second coming Yahshua will triumph over the forces of Evil and those include the God's people, as long as they are overcome with them. But since Yahshua cares for the God's people, he will not come back until they are fully cleansed. ${ }^{137}$

In the movement's religious practice, the image of the Messiah coming for his pure people is well illustrated by the ritual of marriage. The ceremony takes the form of an enactment, in which the groom symbolizes the coming Messiah and the bride repre-

128 "The Voice From Outside the Camp of Organized Religion: Last Day", http://twelvetribes.org, p. 35 .

${ }^{129}$ Acts 3:19-21: "Repent, then, and turn to God, so that your sins may be wiped out, that times of refreshing may come from the Lord, and that he may send the Messiah, who has been appointed for you - even Jesus. Heaven must receive him until the time comes for God to restore everything, as he promised long ago through his holy prophets."

130 “The Voice From Outside the Camp of Organized Religion: Last Day”, http://twelvetribes.org, p. 35.

${ }^{131}$ Matthew 24:14. "The Year of Jubilee” (online), twelvetribes.org, 2013, accessed April 2017, available online at http://twelvetribes.org.

132 “The Voice From Outside the Camp of Organized Religion: Last Day”, http://twelvetribes.org, p. 9.

133 "Pre-enactment of The Marriage of the Lamb" (online), http://twelvetribes.org, 2002, accessed September 2016, available online at http://twelvetribes.org.

${ }^{134}$ Revelation 12:1.

135 “The Voice From Outside the Camp of Organized Religion: Last Day", http://twelvetribes.org, p. 31.

136 “Called to be Saints" (online), twelvetribes.org, 2015, accessed May 2017, available online at http:// twelvetribes.org.

137 "Pre-enactment of The Marriage of the Lamb", http://twelvetribes.org, p. 5. 
sents the God's people, which will unite with the Messiah at the End of Time. During the ritual, both the fiancées and the guests loudly recite biblical texts that contain references to the movement's eschatological expectations. The space in which the wedding is being held has the appearance of a theatrical stage. In the first part of the ceremony the groom awaits the bride near a heavily adorned throne symbolizing the Throne of God. ${ }^{138}$ After a short time of silence that represents Yahshua's waiting for the restoration of God's people, the groom loudly exclaims that the bride is ready. Then he moves to a stage set with clouds that represent the mid-heaven. ${ }^{139}$ From this place, he calls for the bride to join him. At this moment, the bride enters the scene ${ }^{140}$ and her appearance in the mid-heaven represents the reuniting of the faithful part of God's people with Yahshua at the End of Times. During the next part of the ceremony, a dance of warriors follows, which represents an allegory of the final battle of Armageddon. The dancers move in a very dynamic fashion that embodies Yahshua's wrath against the forces of Evil that tortured the Bride while he was waiting for her in the Heavens. ${ }^{141}$ Afterwards, a joyous dance of victory takes place. ${ }^{142}$ The last dramatized part of the ceremony describes the millennial kingdom of Yahshua and his people, including the establishing of his throne in Jerusalem ${ }^{143}$ on which the newlyweds remain for the rest of the ceremony. A wedding supper follows, symbolizing the plenty and richness of the messianic kingdom. ${ }^{144}$ During the feast, the newlyweds exchange vows, expressing the durability of the marriage bond, as well as the covenant between Yahshua and the God's people. The man promises his bride that he will "sacrifice his life for her" and she promises she will "submit entirely to her husband's care."145

This process of restoration, symbolically closed by a wedding ceremony, forms a part of the movement's eschatological expectations and its core basis is the education of children. In order to become husband and wife, the fiancés must spend their adolescence with spiritual preparations. According to the Twelve Tribes, children born into the community are more resistant to sin than other children and after three or four generations, only sinless children fully prepared for the new era should be born. However, before this happens, one of the basic necessities of the life of God's people is a strict upbringing. Separate education of the adolescents serves to consolidate the male and female role: while the girls represent the pure God's people (the Bride), the boys prepare for their service to the resurrected Messiah (the Groom). Through their purity, the girls help fulfill the prophecy of the end of the current era, while the boys are supposed to take active part in its creation. Both male and female children are brought up to obey their parents and God through them. In accordance with the Old Testament, the strictness of the upbringing is secured with punishment by means of

\footnotetext{
${ }^{138}$ Revelation 4:2-3. "Pre-enactment of The Marriage of the Lamb", http://twelvetribes.org, p. 4.

139 "Pre-enactment of The Marriage of the Lamb", http://twelvetribes.org, p. 7.

140 "Pre-enactment of The Marriage of the Lamb", http://twelvetribes.org, p. 7.

141 "Pre-enactment of The Marriage of the Lamb", http://twelvetribes.org, p. 11.

142 "Pre-enactment of The Marriage of the Lamb", http://twelvetribes.org, p. 12.

143 "Pre-enactment of The Marriage of the Lamb", http://twelvetribes.org, p. 12.

144 "Pre-enactment of The Marriage of the Lamb", http://twelvetribes.org, p. 15.

145 "Pre-enactment of The Marriage of the Lamb", http://twelvetribes.org, p. 16.
} 
spanking with a rod. ${ }^{146}$ According to the Twelve Tribes, the rod (a narrow, flexible instrument resembling a balloon stick $)^{147}$ is an ideal chastising instrument designated by God and therefore unlike other physical punishments, its usage has a necessary training effect. ${ }^{148}$ The movement insists that spanking with a rod has the ability to eliminate possible sinful thoughts of the child; $;^{149}$ the parents of the community believe that this type of correction is an expression of parental love. ${ }^{150}$ This opposition between love and punishment on the one side and lack of punishment and hate on the other is based on the thirteenth chapter of the Book of Proverbs. ${ }^{151}$

Girls are raised to become proper mothers for boys, who, in turn, will play the crucial role in the most significant events of the End of Times. ${ }^{152}$ The goal of the Twelve Tribes movement is to raise 144000 servants who, according to the Book of Revelation, will bring Yashua's Second Coming upon the world. ${ }^{153}$ In accordance to the fourteenth chapter of the Book of Revelation, ${ }^{154}$ The Twelve Tribes call these servants "virgin male children". ${ }^{155}$ Every tribe should provide twelve thousands of them. The servants together are called the "Male Child" born from the "woman clothed with the Sun", which represents the God's people. ${ }^{156}$ The Male Child is a "fruit" of the covenant with God's people that will be renewed by Yahshua at the End of Time. ${ }^{157}$

The preparation of the Male Child requires three or four generation of strict and perfectly organized training. ${ }^{158}$ One of its core parts is the Bar Mitzvah ritual - only after this ceremony can the adepts start their transformation into servants that will emerge from the movement in the last era of human history. The preparation usually extends from 12 to 20 years of age. ${ }^{159}$ This also means that boys do not become part of

${ }^{146}$ Proverbs 13:24; 19:18; 22:15; 23:13ff; 29:15 and 2 Samuel 7:14; see also "Our Child Training Manual” (online), question12tribes.com, accessed November 2016, available online at http://question 12 tribes.com/tt-teachings/, p. 72

147 “Our Child Training Manual”, http://question12tribes.com/tt-teachings/, p. 72.

148 "Our Child Training Manual”, http://question12tribes.com/tt-teachings/, p. 72.

149 "Our Child Training Manual", http://question12tribes.com/tt-teachings/, p. 6.

150 "Our Child Training Manual”, http://question12tribes.com/tt-teachings/, p.15.

${ }^{151}$ Proverbs 13:24: "He who withholds his rod hates his son, but he who loves him disciplines him diligently."

${ }^{152}$ An interview by the Author with the Twelve Tribes members during the conference "Současná náboženská scéna. Dvacet let časopisu Dingir” [Contemporary religious scene: Twenty years of the Dingir magazine], Hussite Theological Faculty, Charles University, Prague, 4. 11. 2017.

${ }^{153}$ Revelation 7:4: "And I heard the number of them which were sealed: and there were sealed an hundred and forty and four thousand of all the tribes of the children of Israel."

${ }^{154}$ Revelation 14:4: "These are they which were not defiled with women; for they are virgins. These are they which follow the Lamb whithersoever he goeth. These were redeemed from among men, being the firstfruits unto God and to the Lamb."

155 "The Purpose of Creation \& Redemption", http://twelvetribes.org.

${ }^{156}$ Revelation 12:5: „She gave birth to a son, a male child, who "will rule all the nations with an iron scepter." And her child was snatched up to God and to his throne."

157 "The Purpose of Creation \& Redemption", http://twelvetribes.org, p. 36.

${ }^{158}$ After three or four generations, the sins of the fathers (and sin as such) is supposed to be fully gone. See p. e. “The Purpose of Creation \& Redemption”, http://twelvetribes.org, p. 37.

159 "Bar mitzvah - not loving the world" in: "Child Training Manual II" (online), question12tribes.com, 1997, accessed November 2016, available online at http://question12tribes.com/tt-teachings/, p. 64. 
the eschatological Male Child automatically: they have to deserve this honor. ${ }^{160}$ The strict upbringing administered by their parents is meant to guide the boys, help them in their efforts and, when the apocalyptic events arrive, secure their ultimate success in God's eyes.

\section{Second coming of Yahshua and the change of the ages}

According to the Twelve Tribes, once the God's people are restored and ready, the last days of the present era will come. ${ }^{161}$ The Bride will give birth to a Male Child that is, she will produce 144 thousands of servants - and then she will take refuge in a shelter God has prepared for her in a desert. ${ }^{162}$ This moment of relocation of the God's people into the hideout also starts the countdown of 1260 days that have to pass before Yahshua the Groom comes for his Bride. ${ }^{163}$ During this time, the environmental catastrophe will reach its peak and the kingdoms of Earth will unite under Satan's rule. In this deteriorating land, immaculate boys will preach the Kingdom of God and warn people against God's Final Judgement. ${ }^{164}$ According to the movement's interpretation of the sixth chapter of the Book of Revelation, Satan will kill them one by one. ${ }^{165}$ The Twelve Tribes believe this sacrifice of Male Children (their sons) is required by God. God's people must be like God and therefore must undergo the same sacrifice that, through Yahshua, God himself underwent. ${ }^{166}$

In addition to the servants, two witnesses will be called forth during those 1260 days: according to the Twelve Tribes, they will be killed in the streets of Jerusalem. ${ }^{167}$ Those two witnesses are mentioned in the text of the eleventh chapter of the Book of Revelation, ${ }^{168}$ which states that all the nations will laugh at their bodies with mockery, refusing to bury the corpses. The movement believes that the words of the Revelation will be fulfilled and regardless of the onlookers, the witnesses will be resurrected. ${ }^{169}$

During the last day of the present era, Yahshua will descend into the plane between Heaven and Earth, surrounded by his angels and witnesses (his past faithful followers) ${ }^{170}$ The remaining resurrected followers together with the living faithful

\footnotetext{
160 "Giving Birth to the Male Child", http://question12tribes.com/tt-teachings/.

161 “The Voice From Outside the Camp of Organized Religion: Last Day”, http://twelvetribes.org, p. 32.

162 "The Voice From Outside the Camp of Organized Religion: Last Day", http://twelvetribes.org, p. 32 (Revelation 12:6).

163 “The Voice From Outside the Camp of Organized Religion: Last Day”, http://twelvetribes.org, p. 32 (Revelation 17:14).

${ }_{164}$ “The Purpose of Creation \& Redemption”, http://twelvetribes.org, p. 37.

${ }^{165}$ An interpretation of Revelation 6:9-11 according to "The Voice From Outside the Camp of Organized Religion: Last Day”, http://twelvetribes.org, p. 32.

166 “The Purpose of Creation \& Redemption", http://twelvetribes.org.

167 “The Voice From Outside the Camp of Organized Religion: Last Day”, http://twelvetribes.org, p. 32 .

${ }^{168}$ Revelation 11:9ff.

${ }^{169}$ An interpretation of Revelation 11:11 in "The Voice From Outside the Camp of Organized Religion: Last Day”, http://twelvetribes.org, p. 32.

170 "The Voice From Outside the Camp of Organized Religion: Last Day", http://twelvetribes.org, p. 30; "Pre-enactment of The Marriage of the Lamb", http://twelvetribes.org, p. 4.
} 
hiding in the desert will join Yahshua in his last battle. ${ }^{171}$ According to the Twelve Tribes, the events of the Battle of Megiddo (Armageddon) are described in the Book of Revelation ${ }^{172}$ and they represents Yahshua's necessary and just retribution against the forces of Evil. Only after those can he return the Earth to the One that created it. ${ }^{173}$ The battle will last for thirty days, that is, for one moon: this number is a metaphor for fullness. ${ }^{174}$ The return of the Earth to God's ownership is expressed in the concept of the Jubilee, which the movement associates with the End Time. ${ }^{175}$ According to the Book of Leviticus, every seventh year is supposed to become a year of Sabbath (dedicated to the soil's rest) and after seven times seven years, a Jubilee will come (the return of the soil to its rightful owners). ${ }^{176}$ The reason behind the return of the soil is to declare that except for God himself, nobody owns land permanently. ${ }^{177}$ It seems that the Jubilee's description is an indication that the movement expects an imminent end of the present era - God's rule upon the Earth is supposed to come exactly 49 years after the restoration of God's people began. ${ }^{178}$

In the approaching new era, Yahshua and his people will reign in their millennial kingdom; Yahshua will establish his throne in Jerusalem and together with him, two of his faithful followers will rule. ${ }^{179}$ According to the Twelve Tribes, the Second Coming will make the Jewish nation realize that Yahshua was the Messiah. ${ }^{180}$ Consequently, before the installment of Yahshua's millennial kingdom, the spiritual Israel (the actual God's people) will merge with the natural Israel (the Jews). In the new era's kingdom, Abraham's natural offspring will be given back the Promised Land. ${ }^{181}$ According to the Twelve Tribes, God will thus fulfill the covenant he had sealed with Abraham. ${ }^{182}$

171 “The Voice From Outside the Camp of Organized Religion: Last Day”, http://twelvetribes.org, p. 32.

${ }^{172}$ Revelation 19:11-15:19.

173 "Pre-enactment of The Marriage of the Lamb", http://twelvetribes.org, p. 10.

174 "Pre-enactment of The Marriage of the Lamb", http://twelvetribes.org, p. 10.

175 "The Year of Jubilee", http://twelvetribes.org.

${ }^{176}$ Leviticus 25:10; “The Year of Jubilee”, http://twelvetribes.org.

177 “The Year of Jubilee", http://twelvetribes.org.

${ }^{178}$ Lavin says that the final battle between the Good and the Evil should happen after fifty years of restoration intents of the Twelve Tribes. Lavin, God's People: In Search of a Destiny, loc 462. The expectance of the end of the current era after 49 years of restoration is also attested by a fragment of the interview between Susan Palmer and two elders by the name of Hakam and Yochanan in 1999 in Boston. Palmer, "The Twelve Tribes", p. 67.

179 “The Three Eternal Destinies \#80: Judgment of the Body of Messiah and the Judgment of the Nations" (online), question12tribes.com, 1997, accessed November 2016, available online at http:// question12tribes.com/tt-teachings/.

180 "To the Jew First" (online), twelvetribes.org, 2012, accessed December 2016, available online at http://twelvetribes.org.

181 "To the Jew First", http://twelvetribes.org.

182 “The Voice From Outside the Camp of Organized Religion: Last Day", http://twelvetribes.org. 


\section{The restoration of the creation - the eternal age}

After the millennium, a new age will come - due to its permanent character, the Twelve Tribes call it the eternal age. Nevertheless, before this new era begins, God's judgement will take place. Contrary to the dualistic concept of Heaven and Hell, the Twelve Tribes emphasize the threefold outcome of God's judgement. ${ }^{183}$ The movement deduced its doctrine of the "Three Eternal Destinies of Man" from the Book of Revelation ${ }^{184}$ and it is one of the scarce examples of the movement's idea of how the eternal age will look - in other words, what is the core of God's intention for the creation. According to the Twelve Tribes, the Three Eternal Destinies of Man reflect the fact that in this present era, every human being that has ever been born participates on the image of the eternity. The verses of the last chapter suggest that in the eternity, everyone's place will be determined by the thoughts and acts he or she exhibited during the mortal life. Before the Final Judgment, all people will be resurrected and humankind will be divided into three groups - the unjust, the righteous, and the holy.

The first group consists of those who by God's justice are found to be unjust and morally filthy. ${ }^{185}$ According to the Twelve Tribes, this category comprises of those who act consciously against the natural law and ignore the inborn conscience. The movement insists this is how most of the world lives, since from the position of sinful creation, people cannot effectively resist the forces of Evil that rule the world. The acts of the unjust harm other people - in their egoism, the filthy take advantage of others and gain a supposed profit from it. ${ }^{186}$ The teachings give a list (based on the twenty-first chapter of the Book of Revelation) of specific groups of people considered to be unjust. ${ }^{187}$ According to the Twelve Tribes, God will cast those people into eternal damnation in the lake of fire. ${ }^{188}$ The same fate awaits Satan and his angels. ${ }^{189}$

183 "The Three Eternal Destinies\#148: The Good, the Bad and the Holy, Part 1" (online), question12tribes.com, 1997, accessed November 2016, available online at http://question12tribes.com /tt-teachings/.

${ }^{184}$ Revelation 22:11: "He that is unjust, let him be unjust still: and he which is filthy, let him be filthy still: and he that is righteous, let him be righteous still: and he that is holy, let him be holy still."

185 "The Three Eternal Destinies \#148: The Good, the Bad and the Holy, Part 1", http://question 12tribes.com/tt-teachings/.

186 “Three Eternal Destinies Introduction” (online), twelvetribes.org, 2015, accessed May 2017, available online at http://twelvetribes.org.

${ }^{187}$ Revelation 21:8: "But the fearful, and unbelieving, and the abominable, and murderers, and whoremongers, and sorcerers, and idolaters, and all liars, shall have their part in the lake which burneth with fire and brimstone: which is the second death." "The Three Eternal Destinies \#162 What Happens After the Judgement?” (online), question12tribes.com, 1997, accessed October 2016, available online at http://question12tribes.com/tt-teachings/.

188 “The Three Eternal Destinies \# 162 What Happens After the Judgement?”, http:/ question12tribes .com/tt-teachings/.

189 “The Three Eternal Destinies \#160: Like Adam they have Broken My Covenant” (online), question12tribes.com, accessed November 2016, available online at http://question12tribes.com /tt-teachings/. 
The second group consists of those who are righteous in the eyes of God's righteousness ${ }^{190}$ According to the movement, these are the people who, during their mortal life, acted in agreement to their conscience and in accordance to the natural law. Since they obeyed the commandments of the nations' eternal covenant, an eternal life awaits them in the Kingdom of God. They may belong to different religions and confessions - even Jews, Buddhists or others. ${ }^{191}$ Moreover, even those who declare themselves to be unbelievers may act according to their conscience. The Twelve Tribes base their concept of eternal life for nations on the Books of Revelation ${ }^{192}$ and the prophet Isaiah. ${ }^{193}$

Finally, the third group is the people set apart for God, the holy. Those are the ones who were able to overcome sin in their mortal lives and for that they will be rewarded a special place in the eternity. They will become the dwelling of God the Creator, which the Twelve Tribes, in accordance with the Book of Revelation (Revelation 21:12), call the "New Jerusalem". ${ }^{194}$ The people set apart will be joined by those members of the God's people who were condemned to a second death during the millennial kingdom. The Twelve Tribes consider themselves to be the true God's people and thus believe they belong precisely to this group.

In other words, the eternity will be the restoration of creation and everyone who failed to fulfill God's demand in their mortal life will be excluded from it. Those who followed the eternal covenant even though they lived separately from the God's people as well the holy that fulfilled the destiny of the Chosen people will all live together in the restored world and the forces of Evil will no longer bother them.

\section{Conclusion and theological analysis}

I suggest that the core motif of the Twelve Tribes theology is the intent to return to God's original intention that he had in mind during the creation of the world. This motif is reflected in the movement's struggle to change the current state of the world. By the fulfilment of God's command, its members strive to bring forth a situation that would lead to the end of the present era and bring about the new age. This new era is supposed to be the restoration of the original paradisiacal state that had already existed before it was corrupted by human failure. The Twelve Tribes believe themselves to be a formation of God's people that serves God properly; as thanks for their service, they expect their due in the form of mankind's transformation and a return to God's proximity. From the eschatological point of view, God's people have a duty to exterminate evil in the world and end the lineage of human sin.

\footnotetext{
190 “Three Eternal Destinies Introduction”, http://twelvetribes.org.

${ }^{191}$ PALmer, "The Twelve Tribes", p. 69.

${ }^{192}$ Revelation 21:24-26.

${ }^{193}$ Isaiah 60:11-14.

194 “Three Eternal Destinies Introduction”, http://twelvetribes.org.
} 
According to the Twelve Tribes, God's people's obligation was established during the life of Abraham. He is thought to be the ideal forefather and the movement largely idealizes him, for example by comparing his life to Adam's life in the Garden of Eden. Selected texts of the Old Testament serve for the movement as the basis for insisting that only the first four generations of Abraham's offspring followed in his footsteps. The later generations adopted the customs of the neighboring nations instead and stopped serving God properly. The life of the Early Church follows a similar scenario. With respect to these two biblical role models of God's people, the Twelve Tribes combine elements belonging both to the Jewish and Christian Tradition. Nevertheless, if we are to interpret this fact, we have to keep in mind that the movement itself adopts a critical or outright disapproving stance towards both traditions - it sees them as a result of corruption and decadence of two original intents to become God's people and claims relationship to neither of them. While the Twelve Tribes somehow "imitate" them, they also insist that they are merely trying to repeat the correct acts of the first four generation of Abraham's offspring as well as of the Early Church. Contrarily to both, the movement aims not only to obey God's people's duties temporarily, but intends to fulfill them in the ultimate perspective of the events leading to the end of the current era.

Even though the movement thinks that both of the archetypical models of God's people had the same mission and the same obligations, it believes to recognize a big change of Abraham's covenant in the context of the New Testament. The Chosen people are no longer limited to Abraham's kinship - after the coming of the Son of God, the concept of God's people is opened to society at large. For the adepts who want to become members of God's people, this innovation brings new demands as well as new privileges. The core demand is the fact that after Jesus Christ's coming, it is literally impossible to become a part of God's people without accepting him to be the true Messiah. The privilege, on the other hand, consists of the influence of Jesus' salvation upon the spiritual life of God's people. In the movement's perspective, this influence helps to overcome sin and, finally, to free oneself from death.

The Twelve Tribes find the proof of its status of the true God's people by its ability to celebrate Sabbath properly. They understand the celebration as a sign of God's people, which used to be an attribute of Abraham's offspring as well as of the Early Church. It is essential to persist in celebrating Sabbath, lest the movement should lose its status of God's people in the same manner as its two predecessors did. At the same time, the Twelve Tribes' self-identification with God's people significantly strengthens their eschatological outlook. In this perspective, they see isolated community life as a space in which they put into practice the Kingdom of God - and its manifestation brings about the new era. Even though the movement's communitarian life may provoke concern and worry in society at large, it seems that the teachings rather emphasize active change through spiritual renewal of the community instead of outward revolutionary actions.

The stress on God's people's communitarian life is reflected in the emphasis on the collective and group-related. For example in the movement's theology, questions 
of individual salvation are discussed much less often. Even though the teachings of the Three Eternal Destinies insist every person is judged individually, the group of the holy would only contain members of the God's people. Also, the stress on the spiritual purity of the individual, which is apparent in the movement, ultimately serves the spiritual purity of the community. Its members mostly focus on the task given to the God's people as a whole. If some Twelve Tribes fan tried to adopt their practices without actually joining the community, he could never reach the same result, since it can be only reached collectively. Other expressions of the communitarian character of the movement's theology include its tribal division and the intent to gather 144000 servants (or the Male Child).

The core of the child training's theological motivation are the movement's eschatological convictions. Children's obedience to their parents is an image of their deference to God - as such they can become permanent part of God's people and thus participate on the ultimate restoration. Children are brought up to be obedient: their parents believe this type of upbringing will help them to understand God's authority and have no trouble submitting to it fully. To ensure the child's compliance, the community uses physical punishment in the form of spanking with a rod. The movement considers this type of chastisement to be the ideal way of child behavior correction that was designated by God himself. Due to the God's people's mission, major stress is put on the upbringing of boys between 12 and 20 years of age that will serve (as Male Child) during the events of the End Time; conversely, the girls' purity symbolizes the purity of the God's people. God's people's connection with the eschatological Messiah is expressed in the wedding ceremony. The movement's members consider the form of child upbringing to be designated by God and to ease its strict requirements would represent cultural assimilation to the surrounding world, which is precisely what the Twelve Tribes hold against is predecessors. The movement's specific child training practices make its members feel exceptional and this feeling in turn strengthens the idea they are set apart for God. Consequently, the parenting practices cannot be interpreted as a minor part of theology/practice which is devoid of importance and can be easily corrected in response to outside criticism. In fact, the situation is quite the contrary - these practices represent an expression of this New Religious Movement's core ambitions. The Twelve Tribes' child training's manual explicitly states that to skip spanking means to disobey God's command.

This survey of the Twelve Tribes' theology also helps to determine the role played by the people from the outside world. For instance, it may help to assess the questions of the "safety" of the New Religious Movement, that is, its potential effect on its immediate neighbors. Many theological points may help us understand the movement's relationship to the rest of the society - for example the view of Noah's offspring, the idea of natural law, the criticism of worldly justice and the disapproval of present society. Systematically, their view of the outside world is best expressed in the doctrine of the Three Eternal Destinies, which complements the usually strongly critical accent with a promise of hope for those who (according to the movement's moral 
ideals) act righteously. On the other hand, we cannot ignore the clear division between God's people and the rest of humankind, righteous or not. At the same time, even the criticism of the unjust offers two possible interpretations. On the one hand the movement's doctrine does not allow those people that fail to act according to certain criteria in their lives to participate on the next era's eternal life. But on the other hand, the members of the movement leave the judgment to God and, at present, they take no active stance against those they count among the unjust. Instead, they focus exclusively on their own spiritual purity.

The idea of one's exclusive status and the certainty of one's righteous acts (as opposed to the acts of everyone else) is hardly an exception among other New Religious Movements. In case of the Twelve Tribes we may conclude that all their efforts to fulfill God's intention take place inside of the movement itself. Thus, at least according to this theological analysis, they represent no danger to the surrounding society. On the other hand, two questions remain open. First, should the tension between the movement and the outside world rise, this situation may possibly change. And second, we have no idea of how the movement may transform its theology if the expectations of the imminent coming of a new era prove futile.

\section{REFERENCES}

"Abraham's descendants" (online), question12tribes.com, 1992, accessed October 2016, available online at http://question12tribes.com/tt-teachings/.

"Adam and Eve - Tha Fall" (online), question12tribes.com, accessed November 2016, available online at http://question12tribes.com/tt-teachings/.

“Apostle's Teachings Acts 2:42" (online), question12tribes.com, 1995, accessed October 2016, available online at http://question12tribes.com/tt-teachings/.

“A Suitable Helper" (online), twelvetribes.org, 2015, accessed November 2016, available online at http://twelvetribes.org.

"Back to The Garden" (online), twelvetribes.org, 2014, accessed January 2016, available online at http://twelvetribes.org.

"Bar mitzvah - not loving the world" (online), in: Child Training Manual II, question12tribes.com, 1997, accessed November 2016, available online at http:// question12tribes.com/tt-teachings/, p. 64-66.

"Called to be Saints" (online), twelvetribes.org, 2015, accessed May 2017, available online at http://twelvetribes.org.

"Chosen to Walk Like Abraham" (online), question12tribes.com, 1992, accessed October 2016, available online at http://question12tribes.com/tt-teachings/.

"Community at the Crossroads" (online), twelvetribes.org, 2015, accessed in April 2017, available online at http://twelvetribes.org.

"Earth: The Final Century" (online), twelvetribes.org, accessed May 2017, available online at http://twelvetribes.org.

"Ed Meets Edah" (online), twelvetribes.org, 2012, accessed January 2017, available online at http://twelvetribes.org.

"Faith of Abraham" (online), twelvetribes.org, 2015, accessed October 2016, available online at http://twelvetribes.org.

"Giving Birth to the Male Child" (online), question12tribes.com, 1997, accessed November 2016, available online at http://question12tribes.com/tt-teachings/. 
“Incorporated in Messiah" (online), question12tribes.com, 1995, accessed November 2016, available online at http://question12tribes.com/tt-teachings/.

"Instinctive Knowledge and Second Covenant" (online), question12tribes.com, 1995, accessed September 2016, available online at http://question12tribes.com/tt-teachings/.

"Israel: The Seed of Abraham" (online), twelvetribes.org, 2015, accessed November 2016, available online at http://twelvetribes.org.

Lavin, S. R., God's People: In Search of a Destiny - A Look Into Life in the Twelve Tribes Community, Amazon Digital Services LLC, 2016, 212 p.

“Maladies" (online), twelvetribes.org, 2015, accessed October 2016, available online at http://twelvetribes.org.

"Natural Israel” (online), question12tribes.com, 1992, accessed October 2016, available online at http://question12tribes.com/tt-teachings/.

"Nightfall" (online), twelvetribes.org, 2016, accessed February 2017, available online at http://twelvetribes.org.

"Our Child Training Manual” (online), question12tribes.com, accessed November 2016, available online at http://question12tribes.com/tt-teachings/, $348 \mathrm{p}$.

Palmer, Susan J., “The Twelve Tribes: Preparing the Bride for Yahshua's Return”, Nova Religio 13 (3/2010), p. 59-80.

"Pre-enactment of The Marriage of the Lamb" (online), http://twelvetribes.org, 2002, accessed September 2016, available online at http://twelvetribes.org, 20 p.

"Redemption" (online), question12tribes.com, 1995, accessed October 2016, available online at http://question12tribes.com/tt-teachings/.

"Re-establishment the Covenant" (online), question12tribes.com, 1992, accessed October 2016, available online at http://question12tribes.com/tt-teachings/.

"Restoration of the Sabbath" (online), question12tribes.com, 1995, accessed November 2016, available online at http://question12tribes.com/tt-teachings/.

"Restoring the Ancient Way of Genesis 18:19" (online), twelvetribes.org, 2016, accessed November 2016, available online at http://twelvetribes.org.

"Sabbath - the Signifier" (online), question12tribes.com, 1995, accessed October 2016, available online at http://question12tribes.com/tt-teachings/.

"Suspended Animation" (online), twelvetribes.org, 2016, accessed November 2016, available online at http://twelvetribes.org.

"The Anatomy of the Fall of the First Church" (online), question12tribes.com, 1995, accessed October 2016, available online at http://question12tribes.com/tt-teachings/.

“The Black Box" (online), twelvetribes.org, 2016, accessed March 2017, available online at http://twelvetribes.org.

"The Fall of The First Church" (online), question12tribes.com, accessed November 2016, available online at http://question12tribes.com/tt-teachings/.

"The Gospel of the Cross" (online), twelvetribes.org, 2016, accessed May 2017, available online at http: / / twelvetribes.org.

“The Majestic Ones” (online), twelvetribes.org, 2012, accessed October 2016, available online at http: / / twelvetribes.org.

“The Name Above All Names” (online), twelvetribes.org, 2016, accessed November 2016, available online at http://twelvetribes.org.

“The Parable of Fascination" (online), twelvetribes.org, 2016, accessed November 2016, available online at http://twelvetribes.org.

"The Purpose of Creation \& Redemption," (online), twelvetribes.org, 2016, accessed September 2016, available online at http://twelvetribes.org, 48 p.

“The Three Eternal Destinies: Adam and Messiah" (online), question12tribes.com, 1998, accessed October 2016, available online at http://question12tribes.com/tt-teachings/. 
“Three Eternal Destinies Introduction” (online), twelvetribes.org, 2015, accessed May 2017, available online at http://twelvetribes.org.

"The Three Eternal Destinies \# 80: Judgment of the Body of Messiah and the Judgment of the Nations" (online), question12tribes.com, 1997, accessed November 2016, available online at http:/ / question12tribes.com/tt-teachings/.

“The Three Eternal Destinies \#105: My People Israel, the Holy" (online), question12tribes. com, 1997, accessed November 2016, available online at http://question12tribes.com /tt-teachings/.

“The Three Eternal Destinies\#148: The Good, the Bad and the Holy, Part 1" (online), question12tribes.com, 1997, accessed November 2016, available online at http:// question12tribes.com/tt-teachings/.

"The Three Eternal Destinies \#160: Like Adam they have Broken My Covenant" (online), question12tribes.com, accessed November 2016, available online at http:// question12tribes.com/tt-teachings/.

“The Three Eternal Destinies \#162: What Happens After the Judgement?” (online), question12tribes.com, 1997, accessed October 2016, available online at http:// question12tribes.com/tt-teachings/.

“The Unshakable Certainty" (online), twelvetribes.org, 2012, accessed November 2016, available online at http://twelvetribes.org.

"The Voice From Outside the Camp of Organized Religion: Last Day" (online), twelvetribes.org, 2007, accessed November 2016, available online at http://twelvetribes .org, $48 \mathrm{p}$.

“The Year of Jubilee” (online), twelvetribes.org, 2013, accessed April 2017, available online at http://twelvetribes.org.

“To the Jew First" (online), twelvetribes.org, 2012, accessed December 2016, available online at http://twelvetribes.org.

"What Was Normal Has Become Perverted" (online), question12tribes.com, accessed November 2016, available online at http://question12tribes.com/tt-teachings/.

"Where Did the Gospel Come From?" (online), twelvetribes.org, 2016, accessed August 2016, available online at http://twelvetribes.org.

"Why Twelve Tribes" (online), twelvetribes.org, 2015, accessed November 2016, available online at http://twelvetribes.org.

"Why We Live in Communities" (online), question12tribes.com, 1995, accessed October 2016, available online at http://question12tribes.com/tt-teachings/. 